\title{
Production of suspension fertilizers as a potential way of managing indus- trial waste
}

\author{
Daniel Mikła, Krystyna Hoffmann, ' Józef Hoffmann \\ Wrocław University of Technology, Faculty of Chemistry, Institute of Inorganic Technology and Mineral Fertilizers, \\ ul. Smoluchowskiego 25, 50-371 Wroctaw, Poland \\ ${ }^{1}$ Corresponding author
}

\begin{abstract}
Research on the possibilities of utilizing several waste substances for the production of suspension fertilizers has been carried out. The substances were: sludge from the ALWERNIA S.A. Chemical Plant - a potential source of phosphorous $\left(\sim 20 \%\right.$ by wt. $\left.\mathrm{P}_{2} \mathrm{O}_{5}\right)$ and waste sludge from the production of magnesium sulphates and nitrates in the Złotniki S.A. Chemical Plant - a substance aiding the stability of suspension and magnesite (a source of magnesium). The possibility of chemical activation of clayey minerals through ion exchange was investigated. $\mathrm{Na}_{2} \mathrm{CO}_{3}$ was used for this purpose. Fertilizer samples PK and NPK were found to be highly stable (syneresis $<25 \%$ ). The NPK $+3 \% \mathrm{MgO}$ sample was found to have particularly good properties. The activation of the clayey materials by $\mathrm{Na}_{2} \mathrm{CO}_{3}$ resulted in an increase in the stability coefficient in the case of bentonite SN and clay TIK by 0.88964 and 0.516304 , respectively.
\end{abstract}

Keywords: waste, bentonite, suspension fertilizers, activation.

Presented at VII Conference Wasteless Technologies and Waste Management in Chemical Industry and Agriculture, Międzyzdroje, 12 - 15 June, 2007.

\section{INTRODUCTION}

The chemical industry is a source of numerous wastes from various technological processes. Many of the wastes contain chemical components whereby they could be utilized as raw materials for the production of fertilizers but some of their properties often preclude them from being used as such. The adverse properties include the very high moisture content, the poor solubility and the rather unstable composition. This makes it impossible or difficult to use such substances for the continuous industrial production of solid or liquid solution fertilizers.

Nevertheless wastes unsuitable for the above purposes can be used for the production of suspension fertilizers since the excessive moisture content is no obstacle in this case. Also the nutrients do not have to be completely soluble in water ${ }^{1}$. Moreover, suspension fertilizers are manufactured in units whereby raw materials with a different composition can be used for each product.

This paper presents research on several waste substances which could be utilized for the production of suspension fertilizers. The possibility of using waste sludge from the neutralization of extraction phosphoric acid in the ALWERNIA S.A. Chemical Plant was examined ${ }^{2}$. The substance has a very high moisture content (up to $50 \%$ by wt.) and a very high $\mathrm{P}_{2} \mathrm{O}_{5}$ content $(\sim 20 \%$ by wt.).

The possibility of utilizing waste sludge from magnesium sulphate (ZS) and magnesium nitrate (ZN) production in the ZLOTNIKI S.A. Chemical Plant was also examined. The suitability of the wastes for the use as substances aiding the stability of the suspension system was investigated.

Also studies on the activation of several clayey materials to be used as stabilizers of the suspension for suspension fertilizers were carried out ${ }^{3-5}$.

\section{EXPERIMENTAL}

The chemical composition of the sludge (Tab. 1.) was examined using ICP spectrometry in the Multielemental Analyses Laboratory at Wrocław University of Technology.

Table 1. Elemental composition and moisture content of the postneutralization sludge

\begin{tabular}{|r|l|c|}
\hline No. & \multicolumn{1}{|c|}{ Component or operation } & $\begin{array}{c}\text { postneutralization } \\
\text { sludge }\end{array}$ \\
\hline 1 & Losses due to roasting at $105^{\circ} \mathrm{C}$, wt. $\%$ & 47.48 \\
\hline 2 & Losses due to roasting at $400^{\circ} \mathrm{C}$, wt. $\%$ & 48.55667 \\
\hline 3 & Losses due to roasting at $1000^{\circ} \mathrm{C}$, wt. $\%$ & 49.65 \\
\hline 4 & $\mathrm{P}_{2} \mathrm{O}_{5}$, wt. $\%$ & 42.68 \\
\hline 6 & $\mathrm{Na}_{2} \mathrm{O}$, wt. $\%$ & 39.43333 \\
\hline 7 & $\mathrm{Fe}_{2} \mathrm{O}_{3}$, wt. $\%$ & 0.026667 \\
\hline 8 & $\mathrm{~A}_{2} \mathrm{O}_{3}$, wt. $\%$ & 0.03 \\
\hline 13 & $\mathrm{~Pb}, \mathrm{ppm}$ & 0.5 \\
\hline 14 & $\mathrm{Cr}, \mathrm{ppm}$ & 72.33333 \\
\hline 15 & $\mathrm{Cd}, \mathrm{ppm}$ & 0.0025 \\
\hline 16 & $\mathrm{As}, \mathrm{ppm}$ & 0.5 \\
\hline 17 & $\mathrm{Ba}, \mathrm{ppm}$ & 13 \\
\hline 19 & $\mathrm{Ti}, \mathrm{ppm}$ & 1778.333 \\
\hline 20 & $\mathrm{Cu}, \mathrm{ppm}$ & 11.33333 \\
\hline
\end{tabular}

The compositions of the particular samples were determined on the basis of the compositions of the fertilizers produced in the Experimental Liquid Fertilizer Station in Łagiewniki Średzkie (SNP). Potash salt, $\mathrm{NH}_{4} \mathrm{NO}_{3}$ $\mathrm{CO}(\mathrm{NH})_{2}-\mathrm{H}_{2} \mathrm{O}(\mathrm{RSM})$ and postneutralization sludge were used to make fertilizer samples. Five kinds of samples were made. The samples' compositions were as follows: NPK 3-9.5-12.5 + 3\% MgO, NPK 3-9.5-12.5 + 5\% MgO, PK $10-15+3 \% \mathrm{MgO}$, PK 10-15 + 5\% MgO and PK 10$15+7 \% \mathrm{MgO}$. Raw materials such as potash salt, RSM and postneutralization sludge were used to make fertilizer samples with the added Złotniki sludge. Four samples 
with $\mathrm{ZN}$ added (NPK 3-9.5-12.5 + 1\% ZN, NPK 3-9.5$12.5+3 \%$ ZN, NPK 3-9.5-12.5 + 5\% ZN, KS 25-5+ $5 \% \mathrm{ZN}$ ) and two samples with ZS added (NPK 3-9.5-12.5 $+5 \%$ ZS, NPK 3-9.5-12.5 + 10\% ZS), were made.

Specified amounts of the individual components were weighed out and mixed for 5 minutes in a mixer with a vertical stirrer. Then the samples' physicochemical parameters such as density and viscosity were tested. The viscosity (fluidity) tests consisted in measuring the time for which the liquid was flowing from a standard outflow cup with an outflow nozzle $4 \mathrm{~mm}$ in diameter. Permissible ranges of density and fluidity (density: $1.200-1.400$ $\mathrm{g} / \mathrm{cm}^{3}$, fluidity: $10-15 \mathrm{~s}$ ) were adopted on the basis of the data received from SNP. The suspension was poured into a graduated cylinder with a capacity of $100 \mathrm{ml}$ and the change in the degree of syneresis was monitored for 14 days.

Eight clayey minerals: Cloclay bentonite (France), Most bentonite (the Czech Republic), SPECIAL and SN bentonites (Slovakia), TUR clay (Turoszów, Poland), TIK clay (Ukraine) and UKJ and UKC bentonites (Ukraine) were used in the activation studies which consisted in exchanging $\mathrm{Ca}^{2+}, \mathrm{K}^{+}$and $\mathrm{Mg}^{2+}$ ions for $\mathrm{Na}^{+}$ions. For this purpose $5 \mathrm{~g}$ of mineral would be weighed out into a $250 \mathrm{ml}$ Elenmayer flask and $100 \mathrm{ml}$ of an $\mathrm{Na}_{2} \mathrm{CO}_{3}$ solution with a concentration $0.1,0.5,1.0,1.5$ and $2.0 \mathrm{M}$ were added. The prepared samples were subjected to shaking for 4 hours and then filtered under reduced pressure in order to separate the solid fraction from the filtrate. The deposit remaining on the filter was then dried at a temperature of $110^{\circ} \mathrm{C}$ for $2 \mathrm{~h}$. For further studies $1 \mathrm{~g}$ of the dried mineral was mixed with $100 \mathrm{ml}$ of distilled water and a part of it was poured into a $25 \mathrm{ml}$ graduated cylinder. Then for two weeks (one measurement per $24 \mathrm{~h}$ ) the changes in the volume of the precipitate, the suspension and the clear solution above the suspension were measured. The measurement results were used to calculate the stability coefficient D:

$D=\frac{m_{u} \cdot m_{s} \cdot\left(V_{1}+V_{2}\right)}{V \cdot m_{1} \cdot m_{2}}$

where:

$V_{1}$ - sediment volume $\left[\mathrm{cm}^{3}\right]$

$V_{2}$ - suspension volume $\left[\mathrm{cm}^{3}\right]$,

$V$ - the combined volume of suspension, precipitate and clear liquid $\left[\mathrm{cm}^{3}\right]$,

$m_{1}$ - the weight of the amount weighed out for activation $[\mathrm{g}]$,

$m_{2}$ - the weight of the amount weighed out for tests in graduated cylinders $[\mathrm{g}]$,

$m_{u}$ - the theoretical weight of the amount weighed out for activation $[\mathrm{g}]$,

$m_{s}$ - the theoretical weight of the amount weighed out for tests in graduated cylinders [g].

The coefficient defines the theoretical stability of suspension, which decreases with D. Full stability is reached when the stability coefficient is close to 1 .

\section{DISCUSSION OF RESULTS}

Investigation of the possibility of utilizing postneutralization sludge and magnesite for the production of suspension fertilizers.
The determined degree of syneresis versus time for the fertilizer samples based on postneutralization sludge and magnesite is shown in Figure 1 and Table 2.

The NPK 3-9.5-12.5 + 3\% MgO sample was found to have the best properties. Its viscosity and fluidity are within the fixed ranges and the degree of syneresis after 14 days does not exceed 5\%. Also the PK 10-15 + 3\% MgO sample has good properties. Its viscosity and fluidity are $1.3954\left[\mathrm{~g} / \mathrm{cm}^{3}\right]$ and $13.7 \mathrm{~s}$, respectively and the degree of syneresis after 14 days is $\sim 8.2 \%$. Although the other two tested samples are more stable, both their viscosity and fluidity are outside the fixed ranges.

Table 2. The characteristics of suspension samples

\begin{tabular}{|c|c|c|c|c|c|c|c|}
\hline \multirow[t]{2}{*}{ No. } & \multicolumn{4}{|c|}{$\begin{array}{l}\text { Fertilizer component } \\
\text { content [\%] }\end{array}$} & \multirow{2}{*}{$\begin{array}{l}\text { Density } \\
{\left[\mathrm{g} / \mathrm{cm}^{3}\right]}\end{array}$} & \multirow{2}{*}{$\begin{array}{l}\text { Initial } \\
\text { fluidity } \\
\text { [s] }\end{array}$} & \multirow{2}{*}{$\begin{array}{c}\text { Fluidity } \\
\text { after } 336 \mathrm{~h} \\
\text { [s] }\end{array}$} \\
\hline & $\mathrm{N}$ & $\mathrm{P}_{2} \mathrm{O}_{5}$ & $\mathrm{~K}_{2} \mathrm{O}$ & $\mathrm{MgO}$ & & & \\
\hline 1 & & 10 & 15 & 3 & 1.3954 & 13.7 & 14.0 \\
\hline 2 & & 10 & 15 & 5 & 1.5194 & 15.8 & 16.4 \\
\hline 3 & & 10 & 15 & 7 & - & - & - \\
\hline 4 & 3 & 9.5 & 12.5 & 3 & 1.3992 & 13.2 & 12.8 \\
\hline 5 & 3 & 9.5 & 12.5 & 5 & 1.4830 & 15.4 & 14.8 \\
\hline
\end{tabular}

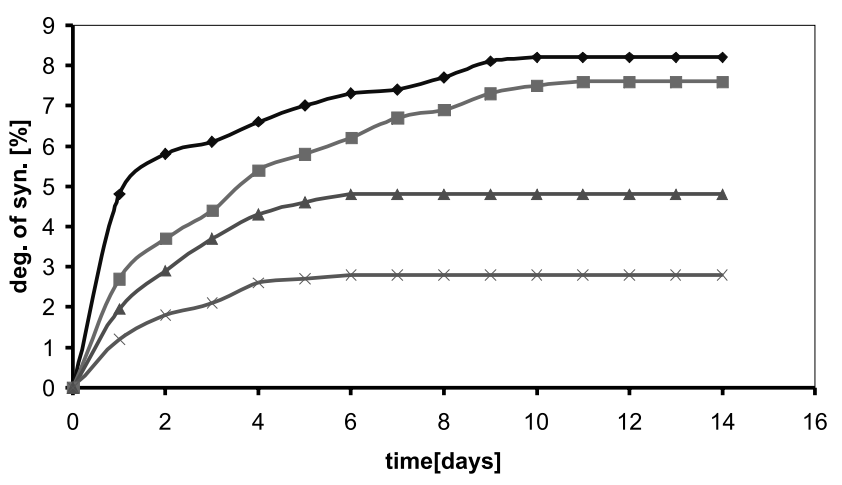

$\leftarrow \mathrm{PK}+3 \% \mathrm{MgO}-\mathrm{PK}+5 \% \mathrm{MgO} \leftarrow \mathrm{NPK}+3 \% \mathrm{MgO} * \mathrm{NPK}+5 \% \mathrm{MgO}$

Figure 1. Change in the degree of syneresis for fertilizer samples NPK and PK with magnesite

Investigation of the possibility of utilizing postneutralization sludge and sludges $\mathrm{ZS}$ and $\mathrm{ZN}$ for the production of suspension fertilizers

The results of the tests carried out for the postneutralization sludge and the $\mathrm{ZS}$ and $\mathrm{ZN}$ sludges are shown in Figure 2 and Table 3.

The NPK 3-9,5-12,5 + 10\% ZS sample was found to have the best rheological properties. But its fluidity was $15.6 \mathrm{~s}$ and so was outside the permissible range. The fluidities and densities of the other samples were within the permissible ranges. Sample NPK $+1 \% \mathrm{ZN}$, for which the degree of syneresis after 14 days was close to $50 \%$, had very poor rheological properties. In the case of the other samples the degree of syneresis was within an interval $\sim 10-23 \%$.

Investigations into the chemical activation of clayey minerals by $\mathrm{Na}_{2} \mathrm{CO}_{3}$

The results of investigations into the chemical activation of clayey minerals are shown in Figs. 3 an 4.

It was found that the stability of suspension systems based on activated clayey minerals increased considerably in the case of bentonite SN and clay TIK. The stability coefficient increased by 0.888 for bentonite $\mathrm{SN}$ and by 
Table 3. The characteristics of suspension samples

\begin{tabular}{|c|c|c|c|c|c|c|c|}
\hline \multirow[t]{2}{*}{ No. } & \multicolumn{4}{|c|}{$\begin{array}{c}\text { Fertilizer component } \\
\text { content [\%] }\end{array}$} & \multirow{2}{*}{$\begin{array}{l}\text { Density, } \\
{\left[\mathrm{g} / \mathrm{cm}^{3}\right]}\end{array}$} & \multirow{2}{*}{$\begin{array}{c}\text { Initial } \\
\text { fluidity } \\
\text { [s] }\end{array}$} & \multirow{2}{*}{$\begin{array}{c}\text { Fluidity } \\
\text { after } 336 \mathrm{~h} \\
{[\mathrm{~s}]} \\
\end{array}$} \\
\hline & $\mathrm{N}$ & $\mathrm{P}_{2} \mathrm{O}_{5}$ & $\mathrm{~K}_{2} \mathrm{O}$ & $\mathrm{ZS}(\mathrm{N})$ & & & \\
\hline 1 & 3 & 9.5 & 12.5 & $1(\mathrm{~N})$ & 1.320 & 10.9 & 10.5 \\
\hline 2 & 3 & 9.5 & 12.5 & $3(\mathrm{~N})$ & 329 & 11.2 & 11.0 \\
\hline 3 & 3 & 9.5 & 12.5 & $5(\mathrm{~N})$ & 1.345 & 11.6 & 11.2 \\
\hline 4 & 3 & 9.5 & 12.5 & $5(S$ & 1.325 & 11.8 & 11.3 \\
\hline 5 & 3 & 9.5 & 12.5 & $10(S)$ & 1.328 & 15.6 & 14.2 \\
\hline 6 & - & - & 25.0 & $5(\mathrm{~N})$ & 1.352 & 17.5 & none \\
\hline
\end{tabular}

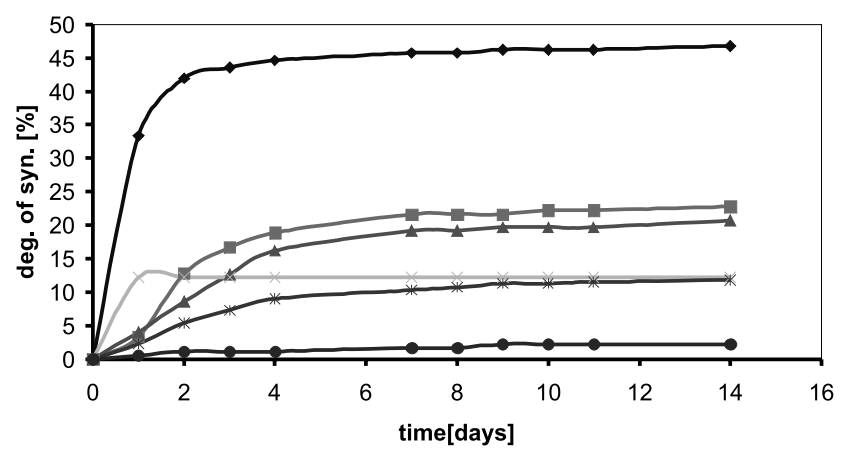

$\rightarrow \mathrm{NPK}+1 \% \mathrm{ZN}=\mathrm{NPK}+3 \% \mathrm{ZN} \neq \mathrm{NPK}+5 \% \mathrm{ZN}$

$-\mathrm{KS}+5 \% \mathrm{ZN} \quad \mathrm{NPK}+5 \% \mathrm{ZS} \rightarrow \mathrm{NPK}+10 \% \mathrm{ZS}$

Figure 2. A degree of syneresis over time for the fertilizer NPK and PK samples with the ZN and ZS sludges

0.789 for clay TIK The optimum concentration of $\mathrm{Na}_{2} \mathrm{CO}_{3}$ at which the best results were obtained was $0.1 \mathrm{M}$ for clay TIK and 1.5M for bentonite SN. In the case of bentonites Special and Most and clay TUR a slight increase in stability - within interval $\Delta \mathrm{D}=0.0165-0.139$ - was noted. No increase in stability was observed for the other clayey minerals.

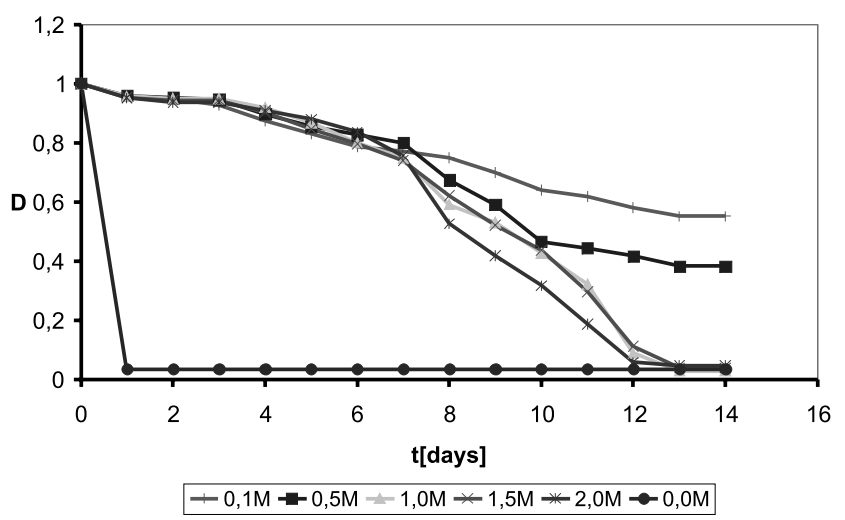

Figure 3. A degree of stability of the suspension system based on the TIK clay versus time

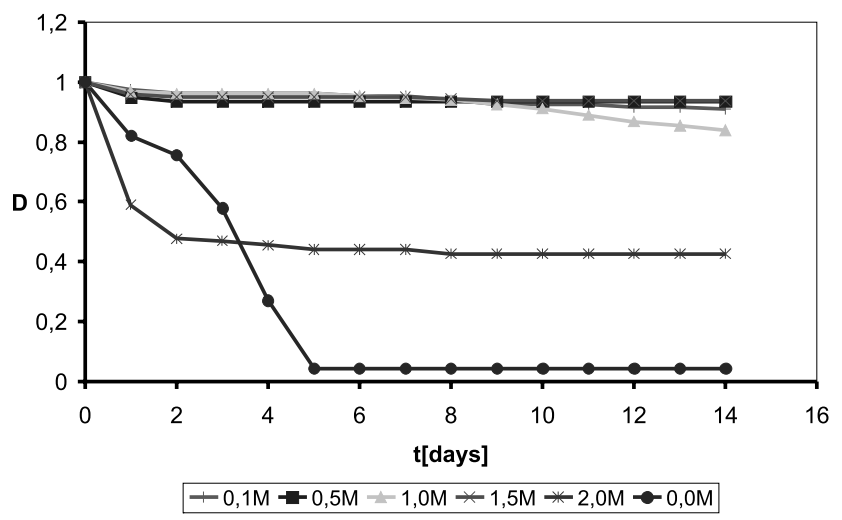

Figure 4. A degree of stability of the suspension system based on the $\mathrm{SN}$ bentonite versus time

\section{CONCLUSION}

Research on the utilization of several waste substances for the production of suspension fertilizers and on the activation of clayey minerals by $\mathrm{Na}_{2} \mathrm{CO}_{3}$ aimed at increasing their suspension system stabilizing properties has been presented. According to its results, fertilizer samples based on postneutralization sludge and magnesite were characterized by high stability and proper viscosity and fluidity.

Fertilizer samples based on postneutralization sludge and sludges ZS and ZN showed satisfactory rheological properties. The sludges should be added in an amount corresponding to $3-5 \%$ of the final composition of the suspension fertilizer samples.

The investigation into the activation of clayey minerals by $\mathrm{Na}_{2} \mathrm{CO}_{3}$ revealed a significant increase in the stability of the suspensions for bentonite SN and clay TIK. In the other cases the increase was small or none at all. The optimum concentration of $\mathrm{Na}_{2} \mathrm{CO}_{3}$ at which the best results were obtained was: $0.1 \mathrm{M}$ for clay TIK and $1.5 \mathrm{M}$ for bentonite $\mathrm{SN}$.

\section{LITERATURE CITED}

(1) Hoffmann J., Górecki H.: Suspension fertilizers new ecological generation of agricultural and garden fertilizers (in Polish), Przemysł Chemiczny 1995, 74, pp. 87 - 91.

(2) Kępiński J.: Inorganic chemical technology (in Polish), PWN, Warsaw, 1974.

(3) Šebek V., Malechowă V.: Zpǔsob aktivacejilovỳch materiálủ, Pat. CSR, no. CS231830 (B1), 1986.

(4) Vetjugov A. V., Voevodin L. I., Mal'tseva V. E.: Sposob aktivacii bentonitowoj gliny, Pat RUS, no. RU2199504C1, 2001.

(5) Kvasha F. S., Zhukov V. V., Aniskovich I. I.: Sposob aktivacii gliniastych matierialov, Pat RUS, no. RU2044587C1, 1995. 